ХАРАКТЕРИСТИКА ОСОБЛИВОСТЕЙ УПРАВЛІННЯ МІЖНАРОДНОЮ ПРОЄКТНОЮ ДІЯЛЬНІСТЮ В ЗАКЛАДАХ ЗАГАЛЬНОЇ СЕРЕДНЬОЇ ОСВІТИ

\title{
CHARACTERISTICS OF MANAGEMENT FEATURES OF INTERNATIONAL PROJECT ACTIVITY IN GENERAL SECONDARY EDUCATION INSTITUTIONS
}

у статті розглянуто та проаналізовано
низку ключових функцій проєктного управ-
ління. Сфрормульовано етапи проєктів та
їхній вплив на ефективність, результатив-
ність і продовження реалізації проєктних
завдань після закінчення проєкту. Зазначено,
що до впровадження системи управління
проєктами варто підходити як до окре-
мого проєкту. Для уникнення проблем під
час підготовки та реалізації даного виду
діяльності потрібно вивчити ситуацію й
озброїти команду необхідними знаннями,
контролювати виконання зобов'язань та
передбачити ризики, створювати атмос-
феру взаємної поваги та мотивувати чле-
нів команди. Керівник має глибоко і всебічно
знати стан справ на кожній ділянці, уміти
виявити чинники, що спричиняють недоліки,
глибоко проаналізувати їх і усунути, пра-
вильно і своєчасно відреагувати на запити
колективу, вживати конкретнихдієвих захо-
дів, заохочувати ініціативу, новаторство,
підтримувати таланти.
окрім того, розкрито особливості управОкрім того, розкрито особливості управління міжнародною проєктною діяльністю та висвітлено ризики проєктного управління в закладах загальної середньої освіти. Виявлено, що основним завданням керівника проєкту є управління командою проєкту. Висвітлено набір професійних $і$ особистих компетенцій, які повинен мати директор закладу освіти як керівник проєкту для ефективного управління командою проєкту, якісної взаємодії із проєктантами, пресою та зовнішніми партнерами. Міжнародні проєкти віднесені до окремої категорії, тому основна увага зосереджена на характеристиці особливостей управління міжнародною проєктною діяльністю в закладах освіти. Визначено чинники еорективності управління, що забезпечують високі результати участі у проєктах. Успіх реалізації й ефрективність досягнення результатів безпосередньо залежать від обраної методологіі управління. Сукупність методологічних правил, законів і прийомів забезпечує базу для формування стратегії управління, чіткого керівничтва у сорері проєктного управління. Управління проектами сьогодні є динамічно розвиненою областю науки $i$ практики менеджменту, актуальність якої з кожним роком тільки зростає.

Ключові слова: проєкт, управління, діяльність, проєктна діяльність, міжнародний проєкт, заклад загальної середньої освіти, освітній простір, управління міжнародною проєктною діяльністю, управління проєктами, міжнародне співробітництво.

A number of key project management functions is discussed and analyzed in the article. The stages of the project are formulated and their impact on the efficiency, effectiveness and continuation of the project tasks after the project is completed. It is stated that the implementation of the project management system should be approached as a separate project. To avoid problems during the preparation and implementation of this activity, you need to study the situation and provide the team with certain knowledge, monitor the fulfillment of obligations and anticipate risks, create the atmosphere of mutual respect and motivate team members. The manager must know deeply and comprehensively the state of affairs at each site, be able to identify the factors that cause deficiencies, analyze them thoroughly and eliminate, respond to the requests of the team correctly and in a timely manner, take concrete, effective measures, encourage initiative and innovation, support talents.

Besides that, the peculiarities of international project activity management are revealed and the risks of project management in general secondary education institutions are highlighted. It is revealed that the main task of the project manager is the project team guidance. The set of professional and personal competences the director of the educational institution, as a project manager, should have for effective management of the project team, quality interaction with designers, the press, and external partners is clarified. International projects fall into a separate category, therefore the main focus is placed on the characteristics of the management of international project activity in educational institutions. The success of the implementation and the effectiveness of achieving its results depends directly on the chosen methodology of management. The set of methodological rules, laws and techniques provide the basis for the formation of management strategies, clear leadership in project management. The factors of management efficiency that provide high results of participation in the projects are identified.

Key words: project, management, activity, project activity, international project, general secondary education institution, educational space, management of international project activity, project management, international cooperation.

Таращанської районної ради Київської області

Постановка проблеми в загальному вигляді. Управління проєктами являє собою окремо розвинену область менеджменту зі своєю методологією, програмними засобами, професійними знаннями, методами й інструментами. Інноваційний досвід свідчить про те, що впровадження проєктної діяльності в закладах освіти дозволяє успішно досягати цілей під час завершення проєкту, поєднувати різні аспекти діяльності, повноцінно використовувати потенціал, збільшує фрінан- сові можливості закладу освіти. Отже, управління проєктами відрізняється від іншої управлінської діяльності, потребує спеціальних умінь, інструментів, організаційної структури та культури, є визнаною особливою галуззю менеджменту. Нині управління проєктами виокремлюється у специфічну галузь знань та передбачає управління з огляду на обсяг, якість, часові, ресурсні та фрінансові обмеження. Вирішити поставлені завдання дозволяють певні підходи до управління проєк- 
тами, що доповнюють один одного: класичний; за циклом вирішення проблеми; за життєвим циклом проєктного менеджменту.

Аналіз останніх досліджень і публікацій. Питання управління проєктами з погляду менеджменту досліджують низка вчених, зокрема: Т. Сорочан, П. Третяков, Л. Батенко, М. Туберозова, Б. Братаніч, Н. Галетова, С. Захаренкова, В. Зотова, М. Лукашенко, Г. Міщенко, Є. Оболенська, О. Панкрухина, Г. Федорова, Н. Шарай, 3. Рябова й ін. У вивчення даної проблеми значний вклад зробили і науковці Л. Батенко, О. Загородніх, Г. Тимошко, В. Ліщинська, Л. Кобиляцький, В. Ящук, О. Полотай, Л. Лук'янова, Г. Єльникова, Т. Махиня й ін. Управління інноваційним розвитком навчального закладу розглядалося у працях таких авторів, як: І. Малкова, Л. Оліфіра, О. Алейнікова, Л. Карамушка, С. Бушуєв, М. Гриньова, Г. Тимошко, Є. Матвишин, В. Морозов, Л. Пономаренко. Проблеми управління проєктами висвітлюють Г. Тарасюк, Л. Даниленко, О. Полотай, Ф. Фрейх, Л. Ноздріна, В. Ящук та ін.

Система поглядів на управління проєктами в закладах освіти формується під впливом реформи освітньої галузі та змін у світовому суспільному розвитку. Конкурентноспроможність закладу освіти визначається його гнучкістю, динамічністю й адаптованістю до вимог навколишнього середовища. В освіті фрормуються нові підходи до управління, розробляються ідеї відкритості шкіл як систем. На фрормування нових вимог до управління проєктами в закладах освіти та запитів щодо розвитку проєктної діяльності впливає розвиток самостійності й активності дітей в освітньому процесі, розвиток вміння пристосовуватися до реальності, вміння співпрацювати 3 людьми в усіх видах діяльності.

Виділення не вирішених раніше частин загальної проблеми. Однак не вирішено багато теоретичних і методичних питань, що стосуються управління міжнародною проєктною діяльністю в закладах освіти з огляду на: місцерозташування закладу освіти, потужність, здатність педагогів до самоосвіти, фрінансові можливості школи і регіону, рівень проєктної компетентності директора закладу освіти. Засадничими є питання вибору технології, за допомогою якої можна успішно реалізувати кожний проєкт, досягти максимальної ефективності у процесі реалізації декількох проєктів в одному закладі освіти. Це є передумовою для проведення більш ґрунтовних досліджень у сорері управління проєктами. Методики й інструменти управління проєктами необхідні для кожного закладу освіти, але, ураховуючи особливості, не кожний заклад освіти потребує однакових інструментів управління проєктами.

Мета статті - на основі аналізу вітчизняної і закордонної наукової літератури та власних напрацювань попередніх періодів визначити особливості управління міжнародною проєктною діяльністю в закладах освіти.

Виклад основного матеріалу. Наука управління проєктами виникла 3 декількох прикладних наук, як-от будівництво, інженерія й оборонна діяльність [2]. Засновником проєктного управління вважають Генрі Ганта, якого називають батьком технік планування та контролю [3]. Він відомий завдяки використанню діаграми Ганта як інструменту управління проєктами.

Діаграма Ганта являє собою відрізки (графрічні плашки), розміщені на горизонтальній шкалі часу. Кожен відрізок відповідає окремому завданню або підзавданню. Завдання і підзавдання, складові частини плану, розміщуються за вертикаллю. Початок, кінець і довжина відрізка на шкалі часу відповідають початку, кінцю і тривалості завдання. На деяких діаграмах Ганта також показується залежність між завданнями. Діаграма може використовуватися для представлення поточного стану виконання робіт: частина прямокутника, що відповідає завданню, заштриховується, відзначаючи відсоток виконання завдання; показується вертикальна лінія, що відповідає моменту «сьогодні».

Часто діаграма Ганта використовується разом із таблицею зі списком робіт, рядки якої відповідають окремо взятому завданню, зображеній на діаграмі, а стовпці містять додаткову інорормацію про завдання [7].

Також засновником проєктного управління вважають Анрі Файоля, який визначив п'ять функцій управління, що фрормують засади знань управління проєктами та програмами [4].

Підхід до управління 3 позицій внутрішніх ресурсів і можливостей організацій як об'єктів управління демонстрували представники шкіл наукового управління, класичної (адміністративної) школи і, пізніше, шкіл людських відносин і поведінкових наук. Так, школа наукового управління, родоначальником якої був Ф. Тейлор, розглядала ефективність спільної праці в організації з позицій витрат часу і руху.

На ефрективність і результативність проєкту впливає детальне дотримання етапів проєкту.

Перший етап - підготовка проєктного завдання й управління інтеграцією проєкту. На першому етапі визначається мета і завдання проєкту. На підставі проєктно-кошторисної документації, ділового листування, протоколів нарад, зустрічей з автором і аудиторією проєкту визначаються об'ємно-вартісні показники, фрінансові, технічні, тимчасові й інші обмеження та допущення.

Другий етап - ініціація, необхідний для ухвалення керівником рішення про початок робіт над проєктом. Рішення ухвалюється на підставі інформації, отриманої на першому етапі в результаті 
аналізу умов контракту. Рішення за проєктом доводиться до всіх зацікавлених осіб.

Третій етап - планування. Даний етап починається зі складання проєкту виконання робіт. У нього входить графік просування робіт із даними про види робіт і їхню тривалість. У графріку відображаються попередні та наступні кроки, виконавці і відповідальні, а також всі необхідні ресурси, спосіб і терміни. За такої деталізації і щотижневого звіту про закінчені роботи ми маємо об'єктивну інорормацію про стан проєкту загалом. На етапі планування повинні бути обумовлені можливі ризики, розроблені попереджувальні та коригувальні дії. Керівник повинен мати необхідні для управління проєктом знання і вміння, на підставі яких фрормується команда проєкту, складається розклад їі роботи.

Четвертий етап - організація. Це остаточне затвердження плану і графріка, структури проєкту, визначені повноваження, обов'язки та відповідальність сторін. Затверджуються терміни, формат і спосіб надання звітності, інфрормації за проєктом. Також необхідно підготувати Статут проєкту і провести його презентацію для засновників закладу освіти.

П'ятий етап - управління і контроль. Це координація дій людей. Взаємодія із замовником із ключевих питань. Щоденний контроль плану-графріку, виявлення й усунення проблем. У разі неможливості виконати роботу згідно із планом відбувається його коригування. На цьому етапі важливі створення єдиного інфрормаційного поля і своєчасна подача інфрормації всіма учасниками проєкту.

Обов'язкові для проєктного управління облік виконаних робіт, визначення початку і закінчення, впорядкування документації, фріксація результатів робіт та збір інфрормації про перебіг їх виконання. Усі ці дані покладаються в основу підсумкового звіту за проєктом.

Шостий етап - завершення. Це останній етап, коли виконані всі роботи за проєктом, завершені всі заходи і проведені відповідні рахунки. Керівник аналізує накопичену інформацію і складає підсумковий звіт щодо проєкту. Звіт містить, крім вищезазначеного, оцінку діяльності команди і партнерів проєкту, рекомендації, засвоєні уроки. Проходить презентація для зацікавлених осіб, створюється архів, у який входять протоколи нарад, звіти про перебіг виконання робіт, звіти про виконання етапів, накази, розпорядження, проєктна документація, архіви листування. Ця інформація необхідна для формування бази даних, на підставі якої відбувається в подальшому аналіз нових проєктів і їх планування.

До впровадження системи управління проєктами варто підходити як до окремого проєкту, тобто необхідно чітко сформулювати його мету і зміст, розробити і затвердити план впровадження і видати відповідний наказ.
Перш ніж розглядати питання про особливості управління проєктною діяльністю, необхідно розглянути і проаналізувати низку ключових фрункцій проєктного управління [1, с. 124]:

1. Бюджетування - визначення вартості проєкту, оцінка бюджету, розроблення тимчасового графріка витрат. Також ключовими завданнями в цьому контексті виступають:

- аналіз ефрективності використання коштів;

- співорінансування з боку закладу освіти;

- урахування інфрляції;

- виначення відсотка можливої економії або довитрат;

- виявлення помилкових витрат.

2. Планування - розроблення загальних і конкретних цілей, їх деталізація та визначення шляхів досягнення цілей, контроль та коригування. Кожен процес планування проходить чотири етапи:

- розроблення загальних цілей;

- визначення конкретних цілей на даний період із подальшою їх деталізацією;

- визначення шляхів і способів досягнення цілей;

- контроль за процесом досягнення поставлених цілей шляхом зіставлення планових показників із фрактичними та коригування цілей.

У процесі планування необхідно відповісти на такі питання:

- що повинно бути зроблено і для чого?

- коли це буде зроблено і хто буде робити?

3. Робота з командою передбачає:

- розроблення матриці відповідальності;

- внутрішню взаємодію з командою;

- пунктуальність і ефрективність використання часу;

- лідерство і мотивацію;

- психологічну атмосфреру;

- завершення існування проєкту розформуванням або трансформацією в іншу управлінську команду.

4. Повторюваність кроків - кожний проєкт має на увазі дії, що повторюються 3 метою вдосконалення підсумкового продукту проєкту, а також виконання базових функцій проєктного управління.

5. Ризики. Іноді виникає ситуація, яка впливає на перебіг проєкту. За причинами виникнення в закладах освіти можливі проєктні ризики таких видів:

- ризик, пов'язаний із нестабільністю законодавства і наявної економічної ситуації, умов інвестування та використання прибутку;

- зовнішньоекономічний ризик;

- ризик несприятливих політичних змін у країні чи регіоні;

- ризик неповноти й неточності інформації проєкту;

- ризик непередбачуваності дій учасників проєкту. 
До окремої категорії проєктів можна віднести міжнародні проєкти. Міжнародними проєктами прийнято називати проєкти, які реалізують для іноземного замовника/партнера як за кордоном, так і на національній території [5, с. 500-503].

Під час реалізації міжнародних проєктів потрібно передбачити тпке: чи буде в реальній ситуації виконано всі проєктні завдання, заходи проєкту? чи будуть досягнуті очікувані результати (проміжні та кінцеві)? чи вистачить запланованих фрінансів і ресурсів? як ухвалити правильне рішення? що робити в разі виявлення проблем? Ці й інші питання постають перед керівником і проєктною командою у процесі управління проєктом.

Управління міжнародною проєктною діяльністю в закладах освіти має деякі особливості:

1. Виконавцями проєкту зазвичай є учні, батьки та вчителі. Члени команди $€$ не тільки працівниками закладів освіти. Під час реалізації довготривалих проєктів є ризик зміни команди (учні та батьки можуть бути членами команди до закінчення школи).

2. Міжнародні проєкти часто мають географічно розсіяні команди. Ці віртуальні команди приходять разом зі своїми власними викликами різними часовими поясами, складними мовними бар'єрами, різним розвитком, потребами та статками.

3. Більшість проєктів тимчасові.

4. Парадокс: члени команди зазвичай мають великий багаж теоретичних знань та повну відсутність практики.

5. Одночасно реалізовуються проєкти від класно-урочного до проєкту МОН, у якому кожний заклад освіти повинен взяти участь. Можливі одночасні проєкти на отримання матеріальної винагороди, специфрічних знань і проходження навчань.

На нашу думку, щоб уникнути проблем із реалізацією проєкту, потрібно вивчити ситуацію на самому початку створення проєкту, забезпечити команду необхідними знаннями. Варто пам'ятати, що протягом всього проєкту знання зростають, а здатність до дій зменшується.

На кожному етапі управління проєктами необхідно:

- регулярно спілкуватися із зацікавленими сторонами;

- контролювати перебіг виконання зобовязань (робота з командою). Постійно аналізувати, які процеси в даний час застосовуються в команді, які вже продемонстрували свою ефрективність? Як працює ваша команда? У якому робочому середовищі ваша команда розвивається найкраще? Якщо ваша команда звикла працювати спільно, утілює нові ідеї в робочому процесі, демонструє гнучкість до змін, команда вважає за краще працювати із чітко визначеним і добре структурованим планом;

- передбачати ризики;
- бути обережним, коли виникають нові ідеї під час реалізації проєкту;

- довіряти інтуїції, ухвалювати виважені рішення.

- створювати атмоссреру взаємної поваги та довіри. Мотивувати та підтримувати учасників команди.

Ми вважаємо, що вибрані інструменти повинні бути простими та зрозумілими, зробити управління проєктом легко, ефективно та мати відповідний шаблон сценарію, який допоможе вам керувати проєктом.

Особливість проєктного управління полягає в делегуванні прав, повноважень і відповідальності за досягнення цілей проєкту одній людині - керівнику проєкту. Його завдання - управляти командою проєкту, взаємодіяти із проєктантами (замовниками), пресою, зовнішніми партнерами. Керівник повинен мати такий набір професійних і особистих компетенцій:

- наявність лідерських якостей;

- знання процесів, етапів та інструментів проєктного управління;

- знання основ сучасного менеджменту;

- уміння вести комплексні та проблемні переговори;

- наявність спеціальної підготовки в галузі проєктування та проєктного менеджменту;

- знання англійської мови на рівні intermediate;

- аналітичні здібності, навики моніторингу й оцінки;

- знання методів і правил бюджетування та бізнес-планування;

- знання методики, досвід побудови бізнеспланів, знання методики розрахунку показників ефективності інвестиційних проєктів, знання методики оцінки ризиків проєкту;

- знання методики побудови оптимізаційних моделей проєктів, бізнес-процесів;

- уміння презентувати проєкт;

- наявність навиків у галузі тайм-менеджменту;

- знання та навички в галузі постановки та контролю виконання завдань;

- бути впевненим користувачем ПК;

- системність, комунікабельність, відповідальність, вміння обстоювати свою думку, спрямованість на результат, стресостійкість;

- уміння проводити зустрічі віп-персон [10].

Під час управління проєктом керівник має такі основні обов'язки, як:

- координація діяльності всіх учасників програми проєкту та здійснення контролю за реалізацією програми відповідно до затвердженої стратегії і концепції;

- ведення щомісячних та річного бюджету проєкту й узгодження з менеджером проєкту;

- моніторинг і оцінка проєкту, коригування проєкту відповідно до узгодженої стратегії; 
- підготовка звітів та іншої документації для зовнішньої комунікації і внутрішніх користувачів;

- ефективне ведення комунікації 3 партнерами, контрагентами, благоотримувачами;

- організація та проведення заходів у межах програми;

- координація, контроль і управління партнерами 3 метою виконання контрактних домовленостей;

- забезпечення залучення експертів до реалізації проєкту;

- розробка календарного плану-графріка проєкту;

- організація роботи проєктної групи (розподіл завдань, мотивація, контроль проміжних і підсумкових результатів);

- проведення діагностики та побудова моделей бізнес-процесів (діаграми потоків даних, діаграми виконання робіт і матриці ухвалення рішень);

- проєктування моделей процесів, «як є», «як має бути»;

- організація впровадження системи: проведення комунікаційних і навчальних сесій, підготовка підсумкових контрольних звітів керуючому органу проєкту;

- організація взаємодії із зовнішніми учасниками 3 питань впровадження проєкту [6].

Висновки. Для забезпечення ефективного і цілеспрямованого управління проєктною діяльністю необхідно обґрунтувати доцільність і можливість нововведення, сорормулювати гіпотезу, спрогнозувати позитивні і негативні наслідки, створити сприятливу морально-психологічну атмосферу в педагогічному колективі, продумати і спланувати теоретичну і методичну підготовку вчителів, забезпечити моральну підтримку проєкту.

Для ефректиного управління проєктом керівник має бути в ролі:

1. Інтегратора - бачити і проєкт, і те, як він вписується в загальний план розвитку закладу освіти, координувати роботу всіх підрозділів команди проєкту.

2. Комунікатора - взаємодіяти з вищим керівництвом, командою проєкту й іншими його учасниками.

3. Лідера команди і творця мікроклімату (задавати напрямок, об'єднувати людей, мотивуватита надихати їх).
4. Мотиватора - зацікавлювати свою команду в успіху проєкту, включаючи як матеріальні, так і моральні чинники.

Основним завданням керівника проєкту $€$ управління командою проєкту. Це контроль і аналіз виконання членами команди доручених робіт, а також урегулювання можливих конфліктів. До обовязків керівника належать:

- управління інтеграцією проєкту (аналіз аналогічних проєктів);

- управління змістом проєкту (договір / контракт; статут проєкту);

- управління термінами проєкту (складання і контроль грасріків робіт);

- управління вартістю проєкту (складання бюджету, контроль витрат і доходів);

- управління якістю (процесний підхід);

- управління людськими ресурсами проєкту (набір, розвиток і управління командою проєкту);

- управління комунікаціями проєкту (формат зв'язку з різними групами й особами, залученими до проєкту, забезпечення команди проєкту необхідною інсрормацією);

- управління ризиками (невизначені події або умови, які можуть вплинути на перебіг проєкту).

\section{БІБЛІОГРАФІЧНИЙ СПИСОК:}

1. Burns P. Entrepreneurship and Small Business: Start-up. Growth and Maturity. Palgrave Macmillan, 2010. $420 \mathrm{p}$.

2. Cleland I. David, Gareis Roland Global project management handbook. Chapter 1 : The evolution of project management. McGraw-Hill Professional, 2006. ISBN 0-07-146045-4.

3. Martin Stevens Project Management Pathways. Association for Project Management. APM Publishing Limited, 2002. ISBN 1-903494-01-X p.xxii.

4. Morgen Witzel. Fifty key figures in management?. Routledge, 2003. P. 96-101. ISBN 0-415-36977-0.

5. Управление проектами : учебное пособие для студентов, обучающихся по специальности «Менеджмент организации» / И. Мазур и др. ; под общ. ред. И. Мазура, В. Шапиро. 5-е изд., перераб. Москва : Омега-Л, 2009. 960 с.

6. Шпильовий В. Проблеми підтримання якості освіти. Управління проєктами та розвиток виробництва. 2000. № 1 (1). С. 30-36.

7. URL: https://gurt.org.ua/vacancies/21128/.

8. URL: https://uk.wikipedia.org/wiki.

9. URL: http://www.ereadr.org/book/biznes/50725-5stadij-upravleniya-proektom-prakticheskoe/2.

10. URL: http://gurt.org.ua/vacancies/21128/. 